\title{
MODEL ARCH(1) DAN GARCH(1,1) PADA PERAMALAN HARGA SAHAM PT. COWELL DEVELOPMENT Tbk.
}

\section{Arch(1) and Garch(1,1) Model in Stock Price Forecasting of Cowell Development Corp.}

\author{
Rosna Ningsih Bilondatu ${ }^{1}$, Nurwan ${ }^{2^{*}}$, Dewi Rahmawaty Isa $^{3}$ \\ ${ }^{1,2,3}$ Jurusan Matematika FMIPA, Universitas Negeri Gorontalo \\ Jln. Jenderal Sudirman, No. 6 Kota Gorontalo, Indonesia \\ e-mail: 1rosnabilondatu@yahoo.com; 2*nurwan@ung.ac.id; 3 dewirahmawatyisa@gmail.com;
} Corresponding author*

\begin{abstract}
Abstrak
Penelitian ini memfokuskan pada peramalan harga saham PT. Cowell Development Tbk. menggunakan data pada Januari 2013 sampai Desember 2016. Hasil analisis diperoleh model terbaik adalah model ARIMA(2,1,12). Hasil pengujian asumsi residual white noise menggunakan uji Ljung-Box menunjukkan bahwa model $\operatorname{ARIMA}(2,1,12)$ merupakan residual white noise. Hasil uji ARCH-LM menunjukkan data mengandung efek heteroskedastisitas atau unsur ARCH. Model yang diajukan dalam penelitian ini adalah ARCH(1) dan GARCH(1,1). Nilai AIC dan BIC terkecil dari dua model ini adalah ARCH(1). Model ARIMA(2,1,12) dengan residual ARCH(1) merupakan model terbaik untuk meramalkan saham PT. Cowel Development Tbk. Penerapan model ARCH(1) untuk meramalkan harga saham PT. Cowel Development Tbk selama 10 hari periode 2013-2016, menunjukkan bahwa peramalan sudah mendekati data faktual dengan nilai MAPE sebesar 0,043\%. Hal ini memberikan indikasi hasil peramalan sudah mendekati data faktual.
\end{abstract}

Kata Kunci : ARIMA, ARCH, GARCH, MAPE, Peramalan.

\begin{abstract}
This study focused on forecasting the stock price of PT. Cowell Development Tbk. using data from January 2013 to December 2016. The results of the analysis are obtained the best model is the ARIMA(2,1,12). The test results residual white noise assume using the Ljung-Box test shows that the model ARIMA(2,1,12) is residual white noise. The ARCH-LM test results show data that contains heteroscedasticity effect or ARCH element. The smallest AIC and BIC values of these two models is ARCH(1). Model ARIMA(2,1,12) with ARCH(1) residual is the best model for forecasting PT. Cowel Development Tbk. Application of model ARCH(1) to forecast the stock price of PT. Cowel Development Tbk for 10 days in the 2013-2016 period, shows that forecasting has approached factual data with $M A P E$ value of $0.043 \%$. This indicates that the forecasting results closer to factual data.
\end{abstract}

Keywords: ARIMA, ARCH, GARCH, MAPE, Forecasting. 


\section{PENDAHULUAN}

Indeks Harga Saham Gabungan (IHSG) merupakan salah satu bentuk pasar modal yang ada di Bursa Efek Indonesia (BEI). Kebijakan pemerintah dalam bidang ekonomi sangat dipengaruhi oleh pergerakan IHSG. Indeks ini menggambarkan keadaan harga-harga saham dari semua perusahaan di Indonesia yang tercatat. Setiap investor dalam perdagangan selalu dihadapkan kepada pilihan membeli atau menjual saham. Para investor harus mempertimbangkan dua hal, yaitu tingkat pengembalian (return) saham dan juga risiko dari investasi saham tersebut. Keuntungan dari mengetahui resiko adalah dapat mengubah perilaku pemilik saham untuk meminimumkan terjadinya risiko. Sedangkan return merupakan keuntungan bagi investor yang melakukan investasi saham [11].

Pergerakan saham terkadang terdapat data yang relatif tinggi dan turun pada waktu tertentu. Keadaan ini merupakan kategori heteroskedastisitas atau adanya gangguan. Kondisi ini dapat diramalkan menggunakan model ARCH (Autoregressive Conditional Heteroskedasticity) [12]. Model ARCH yang dikembangkan oleh Engle pada tahun 1982 dan disempurnakan oleh Tim Bollerslev pada tahun 1986. Penyempurnaan model ini adalah memasukan error term dimasa lalu dan varian error term dimasa lalu. Hasil penyempurnaan model ARCH dikenal dengan nama model Generalized Autoregressive Conditional Heteroscedasticity (GARCH) [12], [1]. Penelitian tentang pasar modal di Indonesia khususnya pada sahamsaham terpilih yaitu Indeks saham LQ 45 melalui penerapan model GARCH. Hasil yang diperoleh menunjukkan bahwa model $\operatorname{GARCH}(1,1)$ memberikan hasil koefisien yang lebih signifikan [2]. Pada dasarnya data runtun waktu tidak semuanya memiliki variansi konstan. Variansi merupakan variabel dalam statistik yang menggambarkan seberapa jauh perubahan data terhadap rata-ratanya. Model ARCH merupakan model autoregresif dalam keadaan variansi tidak konstan. Peramalan dengan model ARCH dapat kita lakukan cukup dengan adanya data runtun waktu tunggal. Peramalan dengan model ini tidak perlu memandang aspek-aspek lain yang dapat mempengaruhi perubahan data runtun waktu. Penelitian ini membandingkan model ARCH (1) dan GARCH $(1,1)$ untuk meramalkan harga saham dengan sampel PT. Cowell Development Tbk.

\subsection{Fungsi autokorelasi (ACF) dan Fungsi Parsial Autokorelasi (PACF)}

Autokorelasi merupakan korelasi antar data pengamatan suatu data runtun waktu. Koefisien autokorelasi untuk lag- $k$ diberikan dengan rumus [3].

$$
\rho_{k}=\frac{E\left(X_{t}-\mu\right)\left(X_{t+k}-\mu\right)}{\sqrt{E\left(X_{t}-\mu\right)^{2}} \sqrt{E\left(X_{t+k}-\mu\right)^{2}}}=\frac{\gamma_{k}}{\gamma_{0}}
$$

dimana:

$$
\begin{aligned}
& \mu \quad=\text { rata-rata } \\
& \gamma_{k}=\text { autokovariansi pada lag- } k \\
& \rho_{k}=\text { autokorelasi pada lag }-k \\
& t \quad=\text { waktu pengamatan, } t=1,2,3 \ldots
\end{aligned}
$$

Fungsi autokorelasi merupakan hubungan antara koefisien autokorelasi dengan lag-nya. Koefisien autokorelasi untuk lag- $k$ dari data runtun waktu diberikan dengan rumus [3].

$$
r_{k}=\frac{\sum_{t=1}^{n-k}\left(x_{t}-\bar{x}\right)\left(x_{t+k}-\bar{x}\right)}{\sum_{t=1}^{n}\left(x_{t}-\bar{x}\right)}
$$

dimana:

$r_{k} \quad=$ koefisien autokorelasi pada lag- $k$

$k \quad=$ selisih waktu

$n \quad=$ jumlah populasi 
$\rho_{k} \quad=$ rata-rata dari pengamatan

$x_{t} \quad=$ pengamatan pada waktu ke-t

$x_{t+k}=$ pengamatan pada waktu ke $t+k, \mathrm{k}=1,2,3 \ldots$

Uji signifikansi dari koefisien autokorelasi mengacu pada hipotesis:

$H_{0}: \rho_{k}=0$; Koefisien autokorelasi tidak signifikan

$H_{1}: \rho_{k} \neq 0$; Koefisien autokorelasi tidak signifikan

Autokorelasi parsial merupakan korelasi antara $X_{t}$ dan $X_{t+k}$ dengan mengabaikan ketidakbebasan $X_{t+1}, X_{t+2}, \ldots, X_{t+k-1}$. Persamaan autokorelasi parsial $X_{t}$ dan $X_{t+k}$ diberikan dengan rumus:

$$
X_{t+k}=\phi_{k 1} X_{t+k-1}+\phi_{k 2} X_{t+k-2}+\ldots+\phi_{k k} X_{t+\alpha t+k}
$$

Uji signifikansi dari koefisien autokorelasi mengacu pada hipotesis:

$H_{0}: \phi_{k k}=0$; Koefisien autokorelasi parsial tidak signifikan

$H_{1}: \phi_{k k} \neq 0$; Koefisien autokorelasi parsial signifikan

Statistik uji:

$$
t=\frac{\phi_{k k}}{S E \phi_{k k}} ; S E \phi_{k k}=\frac{1}{\sqrt{n}}
$$

Kriteria uji: Tolak $H_{0}$ jika $\left|t_{h i t}\right|>t_{\frac{\alpha}{2} d f}[5]$.

\subsection{Model Autoregressive Integrated Moving Average (ARIMA)}

Model ARIMA merupakan gabungan antara model autoregressive (AR) dan moving average (MA). Kedua model tersebut mensyaratkan data yang dianalisis bergerak di sepanjang rata-ratanya yang konstan (stasioner). Jika data tidak stasioner, maka dilakukan proses stasioner data menggunakan proses diferensi.

Model Box-Jenkins biasa disebut dengan dengan model Autoregressive Integrated Moving Average (ARIMA). Box dan Jenkins mempopulerkan metode yang terdiri dari tiga tahap dalam memilih model yang cocok untuk melakukan estimasi dan peramalan data runtut waktu univariat, yaitu identifikasi model, estimasi parameter, dan peramalan [7]. Bentuk umum model ARIMA dengan autoregresif orde ke p dan moving average orde ke $q$ [7]

$$
Y_{t}=\alpha_{0}+\alpha_{1} Y_{t-1}+\ldots+\alpha_{p} Y_{t-p}+\varepsilon_{t}+\beta_{0}+\beta_{1} \varepsilon_{t}+\beta_{2} \varepsilon_{t-1}+\ldots+\beta_{q} \varepsilon_{t-q}
$$

\subsection{Model Autoregressive Conditional Heteroscedastic (ARCH)}

Model Autoregressive Conditional Heteroscedastic (ARCH) digunakan untuk mengatasi error yang tidak konstan dalam data runtun waktu. Model ARCH diperkenalkan pertama kali oleh Engle pada tahun 1982 [3]. Varians error $\left(\sigma_{t}^{2}\right)$ pada Model ARCH sangat dipengaruhi oleh error diperiode sebelumnya $\left(\varepsilon_{t-1}^{2}\right)$ . Bentuk umum dari model ARCH adalah [3]:

$$
\begin{aligned}
& \sigma_{t}^{2}=\alpha_{0}+\alpha_{1} \varepsilon_{t-1}^{2} \\
& \varepsilon_{t}=\alpha_{t} X_{t}
\end{aligned}
$$

dimana:

$\alpha_{0}>0, \alpha_{1} \geq 0$

asumsi: 
$\sigma_{t}$ dan $\varepsilon_{\mathrm{t}}$ saling bebas.

\subsection{Model Generalized Autoregressive Conditional Heteroscedastic (GARCH)}

Model Generalized Autoregressive Conditional Heteroscedastic (GARCH) merupakan pengembangan model ARCH dan diperkenalkan oleh Bollerslev pada tahun 1986. Model GARCH $(p, q)$ sebagai berikut [4], [12]:

$$
\begin{aligned}
& \sigma_{t}^{2}=\alpha_{0}+\alpha_{1} \varepsilon_{t-1}^{2}+\ldots+\alpha_{p} \varepsilon_{t-1}^{2}+\beta_{1} \sigma_{t-1}^{2}+\ldots+\beta_{q} \sigma_{t}-q^{2} \\
& \varepsilon_{t}=\sigma_{t} X_{t}
\end{aligned}
$$

dimana:

$\alpha_{0}>0, \alpha_{i} \geq 0, i=1,2, \ldots, p$

$\beta_{j} \geq 0, j=1,2,3 \ldots, q$

$\alpha_{i}+\beta_{j}<1$

Model GARCH $(1,1)$ dinyatakan dengan rumus:

dimana:

$$
\sigma_{t-1}^{2}=\alpha_{0}+\alpha_{1} \varepsilon_{t-1}^{2}+\beta_{1} \sigma_{t-1}^{2}
$$

$\alpha_{0}>0, \alpha_{1} \geq 0$ dan $\beta_{1} \geq 0$

$\alpha_{t}^{2}=$ variansi dari error pada waktu $t$

$\alpha_{0} \quad=$ komponen konstanta

$\alpha_{1} \quad=$ parameter pertama dari $\mathrm{ARCH}$

$\beta_{1} \quad=$ parameter pertama dari GARCH

$\varepsilon_{t-1}^{2} \quad=$ kuadrat residual pada waktu ke-t

\subsection{Uji Residual White Noise}

Uji residual White Noise menggunakan uji Ljung-Box [3] :

$$
\mathrm{Q}=\mathrm{n}(\mathrm{n}+1) \sum \frac{\hat{\rho}_{\mathrm{k}}^{2}}{n-k}, n>k
$$

Dimana:

$\mathrm{k}:$ lag maksimum

$\mathrm{n}: \mathrm{N}-\mathrm{d}$

$\mathrm{N}$ : Jumlah pengamatan

$\hat{\rho}$ : Autokorelasi residual untuk lag ke- $k$

\subsection{Kriteria Pemilihan Model terbaik dan Forecasting}

Kriteria pemilihan model berdasarkan galat dan galat peramalan [5]. Kriteria pemilihan model berdasarkan analisis galat adalah:

1. Akaike Info Criterion (AIC)

$$
A I C=2 \ln (l)+2 k
$$

2. Schwarz's Bayesian Criterion (SBC) atau Bayesian Information Criterion (BIC)

$$
S B C=-2 \ln (l)+\ln (T) k
$$

dimana:

$$
l=-\frac{R}{2}\left[1+\log (2 \pi)+\log \left(\frac{\varepsilon \varepsilon^{\prime}}{R}\right)\right]
$$


$k$ = banyaknya parameter

$T$ = banyaknya pengamatan

$l \quad=$ nilai fungsi log likelihood

$\varepsilon \varepsilon^{\prime}=$ kuadrat galat

$R$ = banyaknya sisaan

Kriteria pemilihan model berdasarkan galat peramalan menggunakan Mean Absolute Percentage Error (MAPE) [10]:

$$
\text { MAPE }=\frac{1}{T} \sum_{t=1}^{T}\left|h_{t}-\hat{h}_{t}\right| \times 100
$$

dimana:

$l$ = banyaknya data

$l$ = ragam faktual

$\hat{h}=$ ragam dugaan

Peramalan yang optimum terlihat pada galat yang dihasilkan. Semakin kecil galat yang dihasilkan, maka semakin akurat peramalan yang dilakukan.

\section{METODE PENELITIAN}

Tahapan-tahapan dalam penelitian ini terdiri dari:

a. Tahap pertama adalah studi pustaka meliputi: kajian literatur melalui buku teks, jurnal-jurnal yang berkaitan dengan penelitian, dan sumber-sumber online internet. Tahapan ini menjadi dasar untuk melakukan analisis permasalahan yang ditetapkan dalam penelitian.

b. Tahap kedua adalah pengumpulan data. Data diperoleh secara online melalui Finance Yahoo (finance.yahoo.com). Data yang digunakan adalah Harga Saham PT Cowell Development.Tbk dari januari 2013 sampai Desember 2016 [6].

c. Tahap ketiga adalah pengujian data yang diperoleh meliputi: uji stasioneritas data, identifikasi model ARIMA, uji ARCH-LM, identifikasi model ARCH dan GARCH, estimasi parameter, pemilihan model dan peramalan/validasi

d. Tahap keempat adalah penarikan kesimpulan.

Alur penelitian ditunjukkan pada Gambar 1, sebagai berikut: 


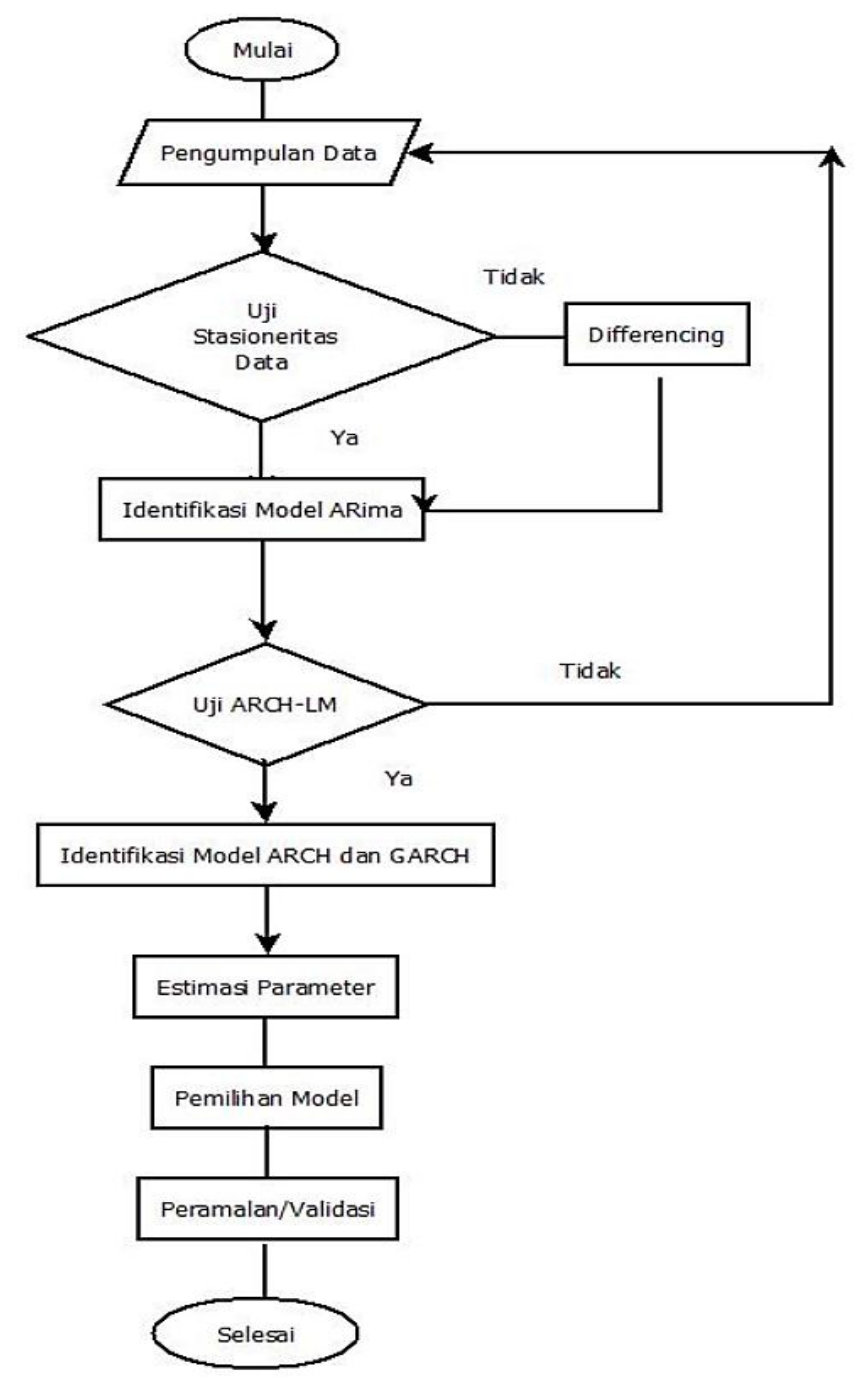

Gambar 1. Alur Penelitian

\section{HASIL DAN PEMBAHASAN}

\subsection{Uji Stasioneritas}

Data yang digunakan dalam penelitian adalah data pada bulan Januari 2013 sampai Desember 2016 yang diperoleh secara online melalui finance.yahoo.com [6]. Data faktual yang digunakan penelitian ini ditunjukkan pada Gambar 2, berikut:

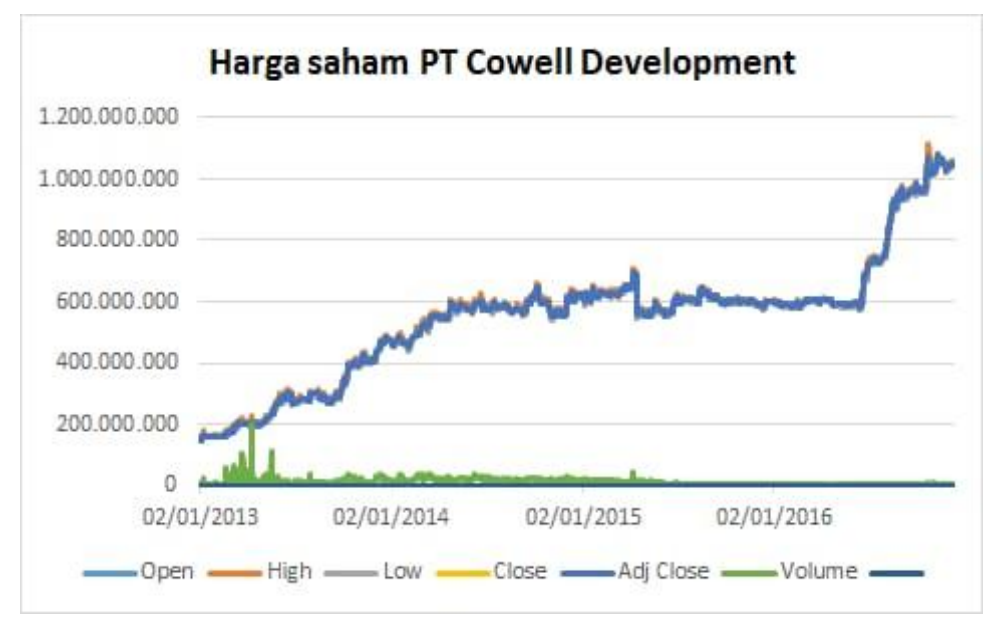

Gambar 2. Data Saham PT. Cowell Development bulan januari 2013 sampai dengan Desember 2016 [6] 
Hasil plot Auto Correlation Function (ACF) menggunakan data asli PT. Cowell Development ditunjukkan pada Gambar 3.

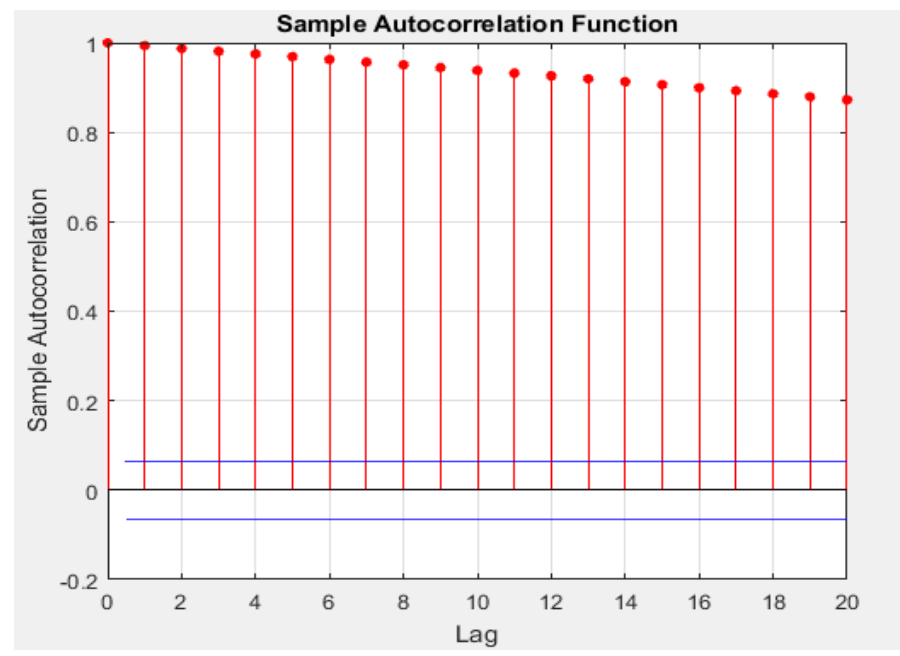

Gambar 3. Plot ACF Data faktual PT. Cowell Development

Berdasarkan plot ACF, terlihat bahwa data faktual tidak stasioner. Oleh karena data tidak stasioner, maka dilakukan differencing satu kali untuk memperoleh data runtun waktu yang baru. Hasil plot data runtun waktu yang baru ditunjukkan pada Gambar 4.

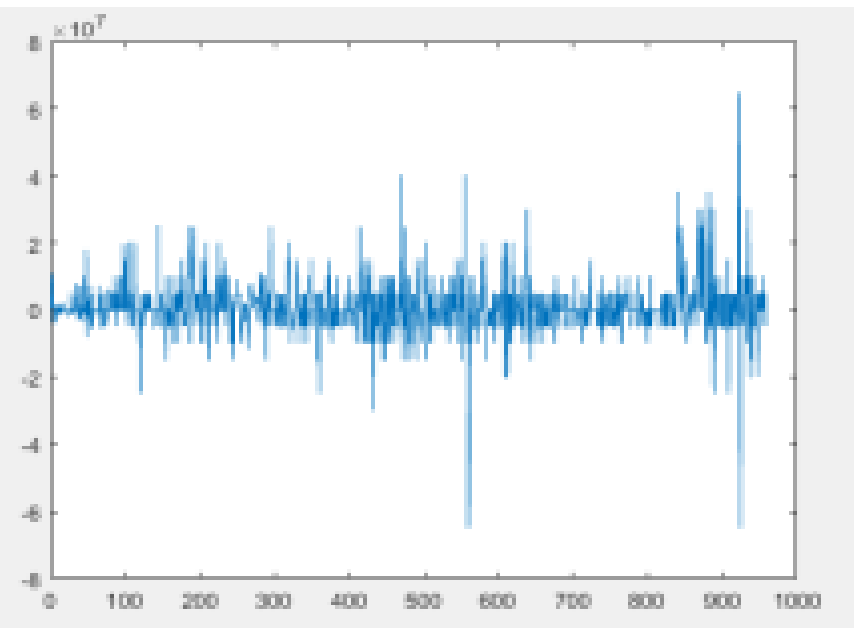

Gambar 4. Plot data setelah dilakukan differencing satu kali

Setelah dilakukan differencing satu kali, kemudian dilakukan plot ACF seperti ditunjukkan pada Gambar 5. 


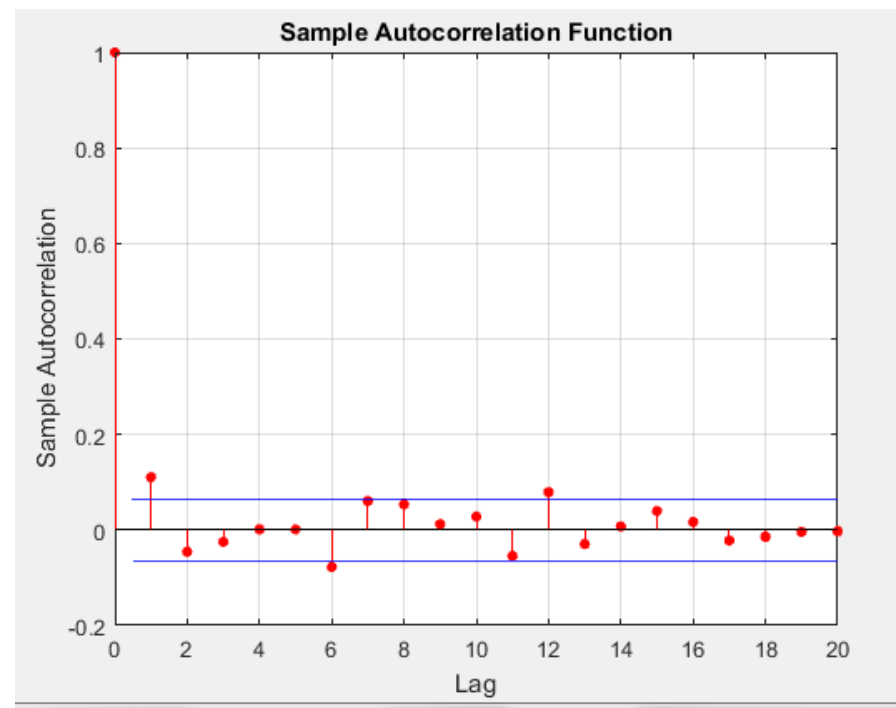

Gambar 5. Plot ACF setelah differencing satu kali

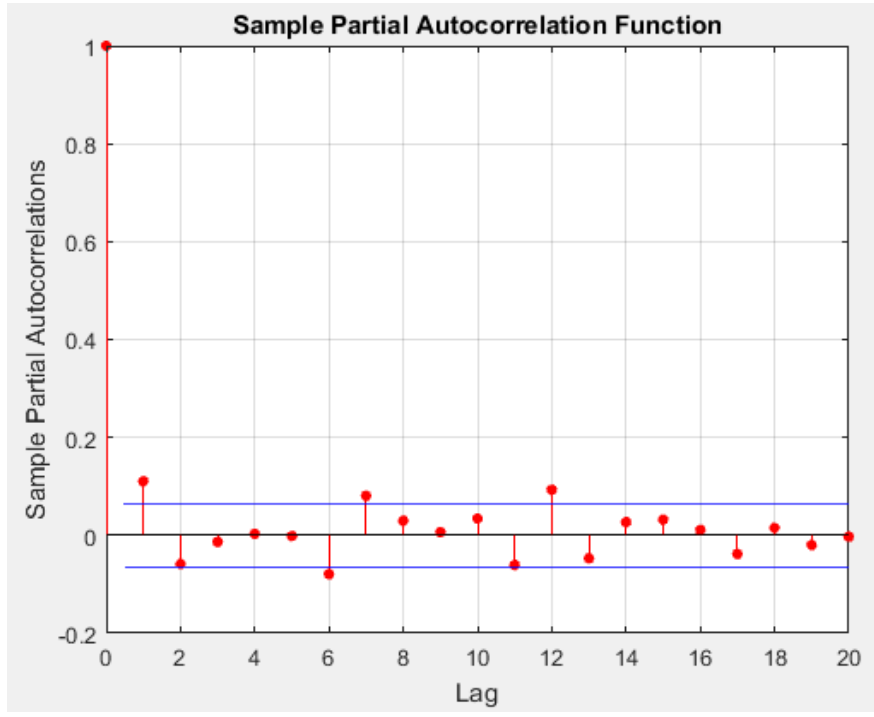

Gambar 6. Plot Partial Autocorrelation Function (PACF)

Berdasarkan plot ACF seperti yang ditunjukkan pada Gambar 5, pada lag ketiga mendekati nol dan plot Partial Autocorrelation Function (PACF) pada Gambar 6 dapat disimpulkan bahwa data stasioner. Berdasarkan grafik ACF dan PACF maka diperoleh model ARIMA sebagai berikut:

$\operatorname{ARIMA}(2,1,2)$ :

hargasaham $=10+0,0223484 A R(1)-0,04685584 R(2)-0,906359 M A(1)-0,0936404 M A(2)+\varepsilon_{t}$

$\operatorname{ARIMA}(2,1,7)$

harga saham $=-7275,54+0,0793687 A R(1)-0,421573 A R(2)-0,952475 M A(1)-0,331 M A(2)-$ $0,338548 M A(3)-0,0460106 M A(4)-0,0012775 M A(5)-0,0583303 M A(6)+0,085676 M A(7)+\varepsilon_{t}$

$\operatorname{ARIMA}(2,1,12)$

harga saham $=9,92975-0,391762 A R(1)+0,520264 A R(2)-0,472476 M A(1)-1,03127 M A(2)+$ $0,395538 M A(3)+0,124289 M A(4)+0,00495544 M A(5)-0,0189549 M A(6)+0,108267 M A(7)+$ $0,0800157 M A(8)-0,099418 M A(9)+0,0189549 M A(10)-0,0574785 M A(11)+0,0349046 M A(12)+\varepsilon_{t}$

$\operatorname{ARIMA}(7,1,2)$

harga saham $=10+0,0894492 A R(1)-0,0607639 A R(2)-0,0172518 A R(3)-0,0077317 A R(4)+$ $0,00808745 A R(5)-0,0957012 A R(6)+0,072224 A R(7)-0,967874 M A(1)-0,0246171 M A(2)+\varepsilon_{t}$ 
$\operatorname{ARIMA}(12,1,2)$

harga saham $=10-0,127725 A R(1)-0,034805 A R(2)-0,0429025 A R(3)-0,00521408 A R(4)-$ $0,00325243 A R(5)-0,0804268 A R(6)+0,0544057 A R(7)+0,0435111 A R(8)+0,00742055 A R(9)+$ $0,0438608 A R(10)-0,0670835 A R(11)+0,0824868 A R(12)-0,736581 M A(1)-0,256181 M A(2)+\varepsilon_{t}$

Dari model ARIMA yang diperoleh, kemudian ditentukan nilai AIC dan BIC untuk menentukan model terbaik. Nilai AIC dan BIC diperoleh sebagaimana ditunjukkan pada Tabel 1.

Tabel 1. Nilai AIC dan BIC Model ARIMA

\begin{tabular}{|c|c|c|}
\hline Model & $\operatorname{AIC}\left(10^{4}\right)$ & BIC $\left(10^{4}\right)$ \\
\hline $\operatorname{ARIMA}(2,1,2)$ & 3,344274145063612 & 3,344274145063612 \\
\hline $\operatorname{ARIMA}(2,1,7)$ & 3,340147231607185 & 3,337947231607185 \\
\hline $\operatorname{ARIMA}(2,1,12)$ & 3,338071402701274 & 3,335871402701274 \\
\hline $\operatorname{ARIMA}(7,1,2)$ & 3,353804679633980 & 3,351604679633980 \\
\hline ARIMA(12,1,2) & 3,353005367113662 & 3,350805367113662 \\
\hline
\end{tabular}

Berdasarkan Tabel 1, diperoleh nilai AIC dan BIC dari ARIMA $(2,1,12)$ adalah 33380,71402701274 dan 33587,1402701274, dengan demikian model $\operatorname{ARIMA}(2,1,12)$ merupakan model terbaik. Tahapan selanjutnya adalah melakukan pengujian asumsi residual white noise menggunakan uji Ljung-Box dengan $\alpha=0,05$. Hasil pengujian diperoleh $p$-value 0.000 lebih kecil dari $\alpha=0,05 \quad(0,000<0,05)$, dengan demikian residual dari persamaan model $\operatorname{ARIMA}(2,1,12)$ merupakan residual white noise.

Dalam penelitian ini, identifikasi unsur heteroskedastisitas pada data yang diamati dilakukan dengan pengujian ARCH-LM. Hasil uji ARCH-LM diperoleh $p$-value 0.000 lebih kecil dari $\alpha=0,05(0,000<0,05)$. Hal ini menunjukkan bahwa data mengandung efek heteroskedastisitas atau unsur ARCH.

Model yang diajukan dalam penelitian ini adalah $\mathrm{ARCH}(1)$ dan $\operatorname{GARCH}(1,1)$, dengan estimasi parameter ditunjukkan pada Tabel 2 .

Tabel 2. Estimasi Parameter Model ARCH(1) dan GARCH(1,1)

\begin{tabular}{|lll|}
\hline Model & Parameter & Estimasi \\
\hline ARCH(1) & $\alpha_{0}$ & 0,000220238 \\
& $\alpha_{1}$ & 0,283139 \\
\hline GARCH(1,1) & $\alpha_{0}$ & $7,55517 \mathrm{e}-06$ \\
& $\alpha_{1}$ & 0,880986 \\
& $\beta_{1}$ & 0,100194 \\
\hline
\end{tabular}

Berdasarkan parameter pada Tabel 2, diperoleh:

model ARCH(1):

model GARCH(1,1):

$$
\sigma_{t}^{2}=0,000218394+0,303958 X_{t-1}^{2}
$$

$$
\sigma_{t}^{2}=7,78176 e^{-06}+0,8764 X_{t-1}^{2}+1,104696 \sigma_{t-1}^{2}
$$

Setelah mengestimasi nilai parameter model ARCH-GARCH, dilakukan pemilihan model terbaik dengan melihat nilai AIC dan BIC terkecil, seperti yang ditunjukkan pada Tabel 3.

Tabel 3. Nilai AIC dan BIC

\begin{tabular}{|l|c|c|}
\hline \multicolumn{1}{|c|}{ Model } & AIC (10 $\left.\mathbf{( 1 )}^{\mathbf{}}\right)$ & BIC (10 \\
\hline ARIMA(1) & 1,466792508988460 & 1,465792508988460 \\
GARCH(1,1) & 1,466801153300554 & 1,466801153300554 \\
\hline
\end{tabular}

Berdasarkan Tabel 3, diperoleh kesimpulan model terbaik yang dapat digunakan untuk meramalkan harga saham PT. Cowel Development Tbk adalah model ARCH (1) karena model tersebut memiliki nilai AIC dan BIC terkecil.

Berikut hasil peramalan harga saham PT. Cowel Development Tbk dalam kurun waktu 10 hari: 
Tabel 4. Perbandingan Data Faktual dan Data Ramalan

\begin{tabular}{|c|c|c|}
\hline Data Faktual & Data Ramalan & Error \\
\hline 1035 & 1000 & 0,033 \\
\hline 1040 & 1000 & 0,038 \\
\hline 1040 & 1000 & 0,038 \\
\hline 1040 & 1000 & 0,038 \\
\hline 1045 & 1000 & 0,043 \\
\hline 1045 & 1000 & 0,043 \\
\hline 1055 & 1000 & 0,052 \\
\hline 1050 & 1000 & 0,047 \\
\hline 1055 & 1000 & 0,052 \\
\hline 1050 & 1000 & 0,04 \\
\hline
\end{tabular}

Berdasarkan hasil yang diperoleh pada Tabel 4, tidak terdapat error yang cukup besar antara data faktual dan hasil ramalan. Peramalan ARCH (1) didapat nilai MAPE sebesar 0,043\%. Nilai MAPE menunjukkan besarnya rataan error yang dihasilkan. Adanya perbedaan antara data faktual dan data ramalan, menunjukkan bahwa semua teknik peramalan tidak akan pernah menyamai data faktual. Hal ini ditunjukkan dengan terdapat selisih atau error antara data faktual dan data ramalan.

\section{KESIMPULAN}

Model terbaik dalam peramalan saham PT. Cowel Development Tbk adalah ARIMA(2,1,12). Hasil pengujian asumsi residual white noise menggunakan uji Ljung-Box menunjukkan bahwa model ARIMA $(2,1,12)$ merupakan residual white noise dibuat model ARCH-GARCH. Dalam penelitian ini dipilih model ARCH(1) dan GARCH(1,1). Dari model ini, diperoleh model terbaik berdasarkan nilai AIC dan BIC terkecil adalah model $\operatorname{ARCH}(1)$. Hasil penelitian menunjukkan model ARIMA(2,1,12) dengan residual ARCH(1) merupakan model terbaik untuk meramalkan saham PT. Cowel Development Tbk. Model ARCH(1) yang diperoleh berdasarkan data penelitian adalah $\sigma_{t}^{2}=0,000218394+0,303958 X_{t-1}^{2}$. Untuk penelitian selanjutnya dapat menggunakan model yang lain seperti TGACRH dan EGARCH dan dapat dibandingkan hasilnya.

\section{DAFTAR PUSTAKA}

[1] A. Widarjono, “Aplikasi Model ARCH Kasus Tingkat Inflasi Indonesia,” Jurnal ekonomi Pembangunan, vol. 7, no. 1, pp. 71-82, 2002.

[2] W. Y. Eliyawati, R. R. Hidayat dan D. F. Azizah, "Penerapan Model GARCH (Generalized Autogressive Conditional Heteroscedaticity) untuk Menguji Pasar Modal Efisien di Indonesia," Jurnal Adminsitrasi Bisnis $(J A B)$, vol. 7, no. 2, pp. 1-10, 2014.

[3] W. W. Wei, Time Series Analysis: Univariate and Multivariate Method, New York: Pearson Education, 2006.

[4] M. S. Lo, Generalized Autoregressive Conditional Heteroscedastic Time Series Models, Simon Fraser University: Simon Fraser University, 2003.

[5] N. Untari, A. A. Mattjik dan A. Saefuddin, “Analisis Deret Waktu dengan Ragam Galat Heterogen dan Asimetrik," Forum Statistika dan Komputasi, vol. 14, no. 1, pp. 22-33, 2009.

[6] C. JK, "https://finance.yahoo.com/," PT Cowell Development Tbk, 01 April 2018. [Online]. Available: https://finance.yahoo.com. [Diakses 1 January 2018].

[7] W. Enders, Applied Econometric Time Series, United States : Wiley Series in Probability and Statistics, 1995.

[8] S. Makridakis, S. C. Wheelwright dan R. J. Hyn, Forecasting methods and applications, United States: John wiley \& sons, 2008.

[9] T. Bollerslev, “Generalized Autoregressive Conditional Heteroskedasticity," Journal of Econometrics, vol. 31, no. 3, pp. 307-327, 1986.

[10] Cryer, J. D, Chan dan Kung-Sik, Time Series Analysis, Lowa: Springer, 2008. 